\title{
UTILIZAÇÃO DA CARTA TOPOGRÁFICA E SIGs PARA A AVERIGUAÇÃO DO CUMPRIMENTO DO CÓDIGO FLORESTAL PARA ÁREAS DE APPS
}

\author{
Cássia Maria Bonifácio ${ }^{1}$ \\ Fernando Luiz de Paula Santil ${ }^{2}$
}

\section{RESUMO}

O uso da carta topográfica em conjunto com sistemas de informação geográfica possibilita o mapeamento e monitoramento de áreas, para muitos fins. Desse modo, buscou-se a utilização dessas técnicas e ferramentas para a análise fisiográfica da bacia hidrográfica do ribeirão Sória, no município de Astorga - PR, juntamente com a averiguação da conformidade das áreas de preservação permanente (APP), buscando uma comparação entre os anos de 2011 e 2015, pré e posterior ao Código Florestal vigente. Este estudo mostrou que as APPs tiveram um acréscimo de $0,14 \mathrm{~km}^{2}$, ao longo dos anos, mas, ainda apresentam muitas áreas em não conformidade com a Lei. Sendo assim, o uso das técnicas cartográficas se mostrou eficiente para a análise da Legislação.

PALAVRAS-CHAVE: Código Florestal, Carta topográfica, APP.

\section{LETTER OF SURVEYING AND USE GIS FOR COMPLIANCE WITH THE FINDING OF THE FOREST CODE FOR APP AREAS}

\begin{abstract}
The use of topographic maps in conjunction with geographic information systems enables the mapping and monitoring areas for many purposes. Thus, we sought to use these techniques and tools for analysis of physiographic basin of Sória creek in the town of Astorga - PR, along with the investigation of the compliance of permanent preservation areas (APP), looking for a comparison between years 2011 and 2015, pre and after the current Forest Code. This study showed that the APP had increased by $0,14 \mathrm{~km}^{2}$, over the years, but still has many areas in noncompliance with the law. Thus, the use of cartographic techniques proved to be efficient for the analysis of legislation.
\end{abstract}

KEYWORDS: Forest Code, Topographic Charter, APP.

\footnotetext{
${ }^{1}$ Doutoranda em Geografia, Universidade Estadual de Maringá, Bolsista CNPq. cassiabonifacio@hotmail.com

2 Prof. Dr. do Departamento de Engenharia de Agrimensura e Cartográfica, Universidade Federal de Uberlândia.
} 


\section{CARTA DE LA ENCUESTA Y USO SIG PARA EL CUMPLIMIENTO DEL HALLAZGO DEL CODIGO FORESTAL PARA ÁREAS APP}

\section{RESUMEN}

El uso de mapas topográficos en conjunción con sistemas de información geográfica permite el mapeo y monitoreo de áreas para muchos propósitos. Por lo tanto, hemos tratado de utilizar estas técnicas y herramientas para el análisis de la cuenca hidrográfica arroyo Sória arroyo en la ciudade de Astorga - PR, junto con la investigación del cumplimiento de las áreas de preservación permanente (APP), en busca de una comparación entre años 2011 y 2015, antes y después de que el Código Forestal actual. Este estudio demostró que la APP aumentó en $0,14 \mathrm{~km}^{2}$, con los años, pero todavía tiene muchas áreas en el incumplimiento de la ley. Por lo tanto, el uso de técnicas cartográficas demostró ser eficaz para el análisis de la legislación.

PALABRAS CLAVE: Código Florestal, Carta topográfica, APP.

\section{INTRODUÇÃO}

A bacia hidrográfica atualmente configura-se como uma das principais unidades de gerenciamento territorial disponível para as atividades agrossilvopastoris. Entretanto, em função do processo de desenvolvimento urbano, as bacias hidrográficas têm sofrido alterações na estrutura física dos canais, no aporte de sedimentos, na composição da biota, e no regime hidráulico (GUERRA, 2003 \& SANTOS, 2004).

O regime de vazão dos cursos d'água e a qualidade de água decorrem de mecanismos naturais, desenvolvidos ao longo de processos evolutivos, da paisagem. Dentre estes mecanismos é possível mencionar a relação que existe entre a cobertura vegetal e a água, especialmente nas cabeceiras dos rios onde estão suas nascentes.

Todavia, é importante destacar que a cobertura vegetal, ao longo dos cursos d'água, sofreu alterações com o Código Florestal vigente, e, sendo assim, nem todas as áreas e imóveis rurais estão em acordo com o estipulado por Lei.

Desse modo, o uso da carta topográfica juntamente com sistemas de informação geográfica, pode ser considerado um importante instrumento para mapear e monitorar áreas, a fim também de auxiliar no cumprimento das leis ambientais.

Neste contexto, o objetivo deste trabalho foi de realizar uma análise fisiográfica da bacia hidrográfica do ribeirão Sória, em Astorga - PR, e de averiguar a 


\section{Periádica Eletrânica

conformidade das Áreas de Preservação Permanente, conforme o Código Florestal vigente, através da utilização de dados cartográficos e Sistemas de Informação Geográfica (SIGs).

\section{MÉTODOS Área de estudo}

O município de Astorga, onde está localizada a bacia hidrográfica do Ribeirão Sória, tem uma área de $446,626 \mathrm{~km}^{2}$ e está totalmente dentro da bacia do Rio Pirapó (PR).

Quanto às condições climáticas a área está submetida ao clima subtropical úmido mesotérmico, com verões quentes, sem estação seca definida e geada pouco frequente (MAACK, 1968). A cobertura vegetal original da região, por sua vez, fazia parte da Floresta Estacional Semidecidual da bacia do Paraná (IBGE, 1992).

Com relação à geologia, assim como das formas e declividades das vertentes, se reflete nos tipos e distribuição das classes de solos. $\mathrm{Na}$ bacia hidrográfica do Sória (Figura 1) apresenta arenitos no topo do interflúvio, onde aparece o Latossolo Vermelho de textura média, e sobre os basaltos, também em posição de topo, ocorre o Latossolo Vermelho férrico de textura argilosa (BONIFÁCIO, 2013).

Figura 1: Localização da bacia hidrográfica do ribeirão Sória.

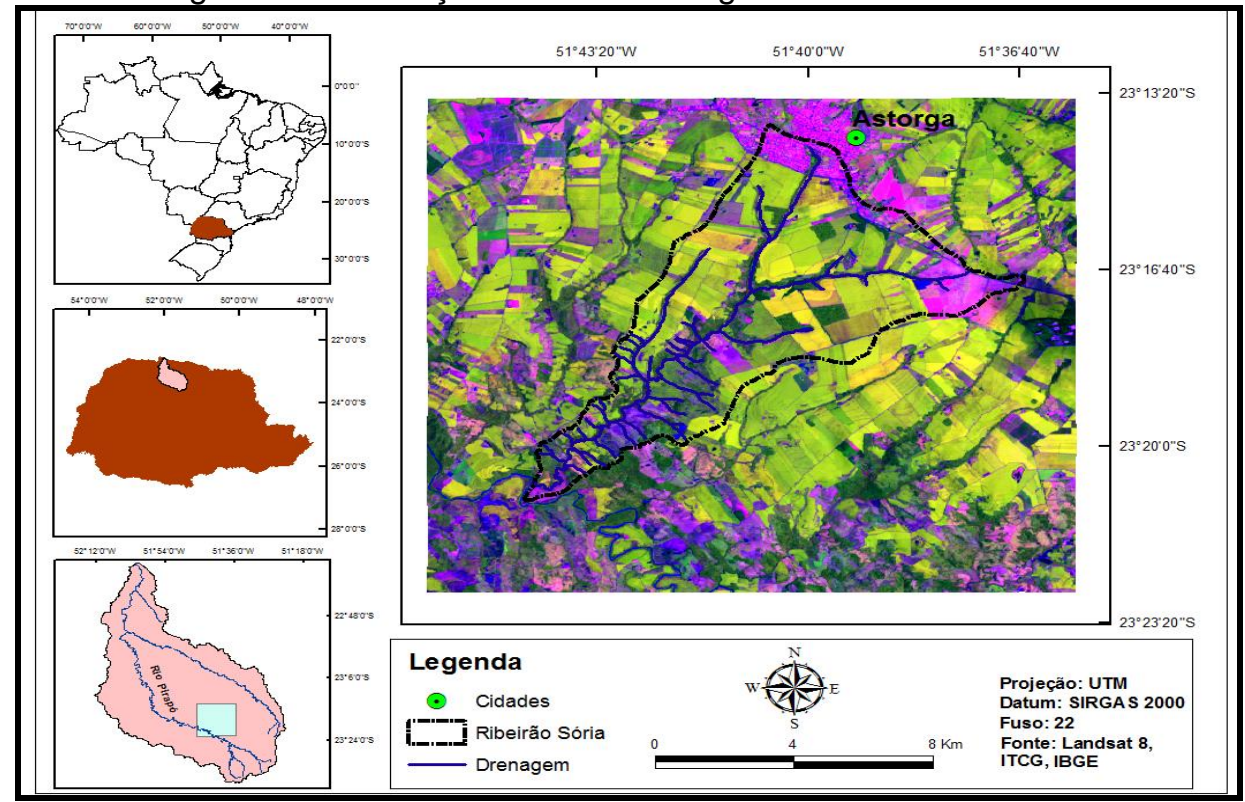




\section{Carta topográfica}

Para a realização do trabalho utilizou-se a carta topográfica elaborada pela Diretoria de Serviço Geográfico do Exército Brasileiro (Brasil, Ministério do Exército 1980 e impressa em 1990), em escala 1:50.000, referente a folha SF.22-Y-D-II-2 MI-2757-2 do município de Astorga - PR. Essa carta está disponível no sítio do Instituto de Terras Cartografia e Geociências do Estado do Paraná (ITCG) no formato TIFF.

Após baixar a imagem, a carta foi georreferenciada no aplicativo ArcMAP, que vem no pacote do ArcGIS 9.3, seguindo a operação de pontos de controle em vários pontos da carta, utilizando as coordenadas geográficas destes pontos paleta Georreferencing e Add Control Points. Para esse procedimento utilizou-se um mínimo de 20 pontos de controle na carta. De acordo com Nogueira Júnior (2003) e Bravo \& Santil (2013) o número de pontos mínimo para a execução da avaliação posicional deve ser de 20 pontos, em função do intervalo de confiança de $95 \%$, obedecendo ao critério de homogeneidade.

Para a carta de uso do solo foi utilizada a Imagem Landsat 8, fuso 22, Datum SIRGAS 200 e projeção UTM, referente ao ano de 2015. As classes de interesse foram: reflorestamento, mata, culturas, pastagem e área urbana. $O$ aferimento das áreas se deu pelo software Google Earth PRO.

\section{Parâmetros morfométricos da bacia hidrográfica do ribeirão Sória}

Para a interpretação fisiográfica da bacia fez-se necessário a utilização dos dados no formato vetorial, devido à maior precisão e praticidade (FINOTTI et al, 2011 \& POLIZEL, ROSSETTI, 2013). Para obtenção da área e perímetro da bacia e comprimentos da rede de drenagem utilizou-se a ferramenta Calculate Geometry do software ArcGIS 9.3.

Para a análise areal se utilizou dos índices das medições planimétricas e das medições lineares, sendo avaliados os seguintes índices: densidade da drenagem (Dd), índice de circularidade (Ic) e/ou índice de forma (Kf), ambos empregados para determinar a forma das bacias, a declividade média, índice de 
rugosidade, índice de sinuosidade e variação hipsométrica das bacias hidrográficas analisadas.

\section{Parâmetro de análise para verificação do cumprimento da Lei}

Para a geração do Buffer para a delimitação das APPs ou faixas marginais fez se necessário selecionar o módulo Arc Toolbox do programa ArcGIS 9.3, e, após isso eleger todo o leito do rio, e preencher as informações dos valores das zonas marginais na tabela de atributos, que, e por fim criar o buffer separadamente primeiro de um lado do rio e depois do outro. Para os cursos d'água foi estabelecida a faixa de 30 metros para a projeção da APP, e um raio de 50 metros para nascentes de olhos d'água.

Esta ferramenta se torna de grande importância para a averiguação da vegetação na área selecionada, pois, a partir da geração deste buffer, em conjunto com a carta de uso do solo, é possível aferir quais locais estão em acordo com o estabelecido pelo Código Florestal.

\section{RESULTADOS}

A carta topográfica do município de Astorga - PR foi georreferenciada no aplicativo ArcMAP, onde foram demarcados pontos de controle (Figura 2), ao longo da carta (citados anteriormente). 
Figura 2: Seleção dos pontos de controle para o georreferenciamento.

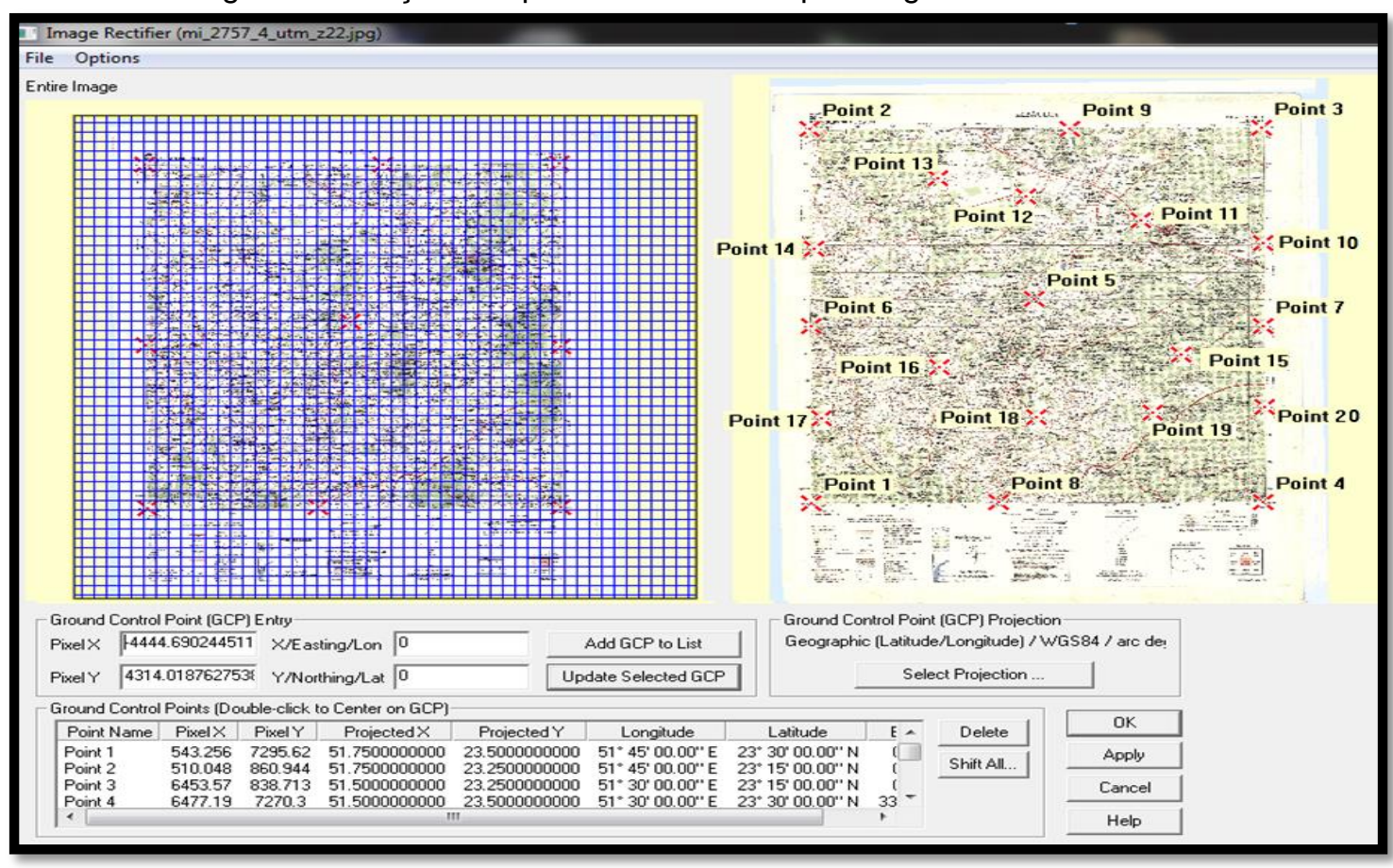

Quanto à morfometria, foi possível estabelecer os limites, a área ocupada pela bacia hidrográfica entre outros parâmetros, como se observa Tabela 1.

Tabela 1: Morfometria da bacia hidrográfica do ribeirão Sória.

\begin{tabular}{lll}
\hline Índices & Unidade & Resultados \\
\hline Área $(\mathrm{A})$ & $\mathrm{km}^{2}$ & 59,24 \\
Altitude máxima & $\mathrm{m}$ & 710 \\
Altitude mínima & $\mathrm{m}$ & 411 \\
Amplitude altimétrica & $\mathrm{m}$ & 299 \\
Densidade de drenagem & $\mathrm{km} / \mathrm{km}^{2}$ & 0,65 \\
Declividade média $(\mathrm{Dm})$ & $\%$ & $6,0 \%$ \\
Fator de forma (Kf) & adimensional & 0,28 \\
Índice de circularidade $(\mathrm{Ic})$ & adimensional & 0,53 \\
Índice de rugosidade $(\mathrm{Ir})$ & adimensional & 2,17 \\
Sinuosidade & adimensional & 1,02 \\
Perímetro $(\mathrm{P})$ & $\mathrm{km}$ & 37,637 \\
\hline
\end{tabular}

Com base nos resultados indicados na Tabela 1, é possível observar que densidade de drenagem da bacia do Sória é de $0,65 \mathrm{~km} / \mathrm{km}^{2}$, que a caracteriza como bacia mediana, conforme as proposições de Beltrame (1994).

O índice de circularidade foi de 0,53 tendendo ligeiramente para formas mais circulares, em que, dependendo do solo e tipo de uso e ocupação, os riscos de inundação serão maiores, assim como induz o fator de forma (Kf) de 0,28. 0 


\section{Fórum Ambiental}

da Alta Paulista

Volume 11, Número 06, 2015

traçado dos canais do ribeirão mostrou que o Sória apresenta um traçado regular $(1,02)$.

A carta de uso do solo (Figura 3) retrata a condição atual de exploração econômica desenvolvida nesse espaço geográfico.

Figura 3: Uso do solo da bacia hidrográfica do ribeirão Sória (2015).

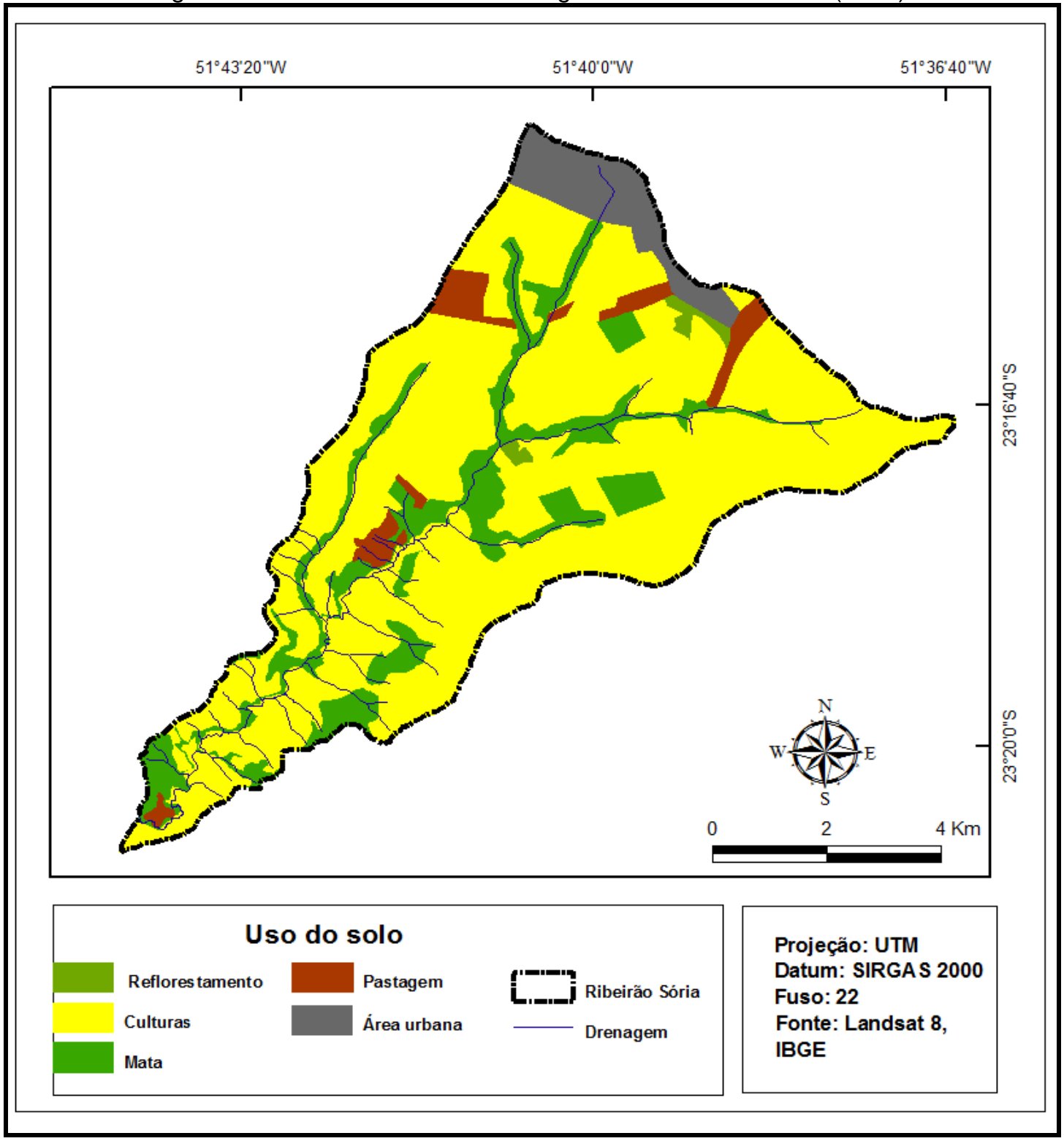

A bacia hidrográfica do Sória apresenta uso e ocupação mista, ou seja, possui parte da área urbana, município de Astorga, ao Norte, e área agrícola, com predomínio de culturas temporárias (soja e milho) e pastagens (gado de corte e leiteiro), assim como manchas de reflorestamento e mata. 


\section{Fórum Ambiental}

da Alta Paulista

Volume 11, Número 06, 2015

Para as APPs foi estabelecido o padrão vigente no Código Florestal de 26 de maio de 2012, que define uma área de 50 metros para nascentes e olhos d'água, assim como 30 metros, a partir da borda do nível regular do curso d'água, para rios de até 10 metros de largura, o que caracteriza a bacia em questão. Ao que se refere às faixas estipuladas para áreas de Preservação Permanente é possível observar na Figura 4.

Figura 4: Áreas de Preservação Permanente na bacia hidrográfica do ribeirão Sória.

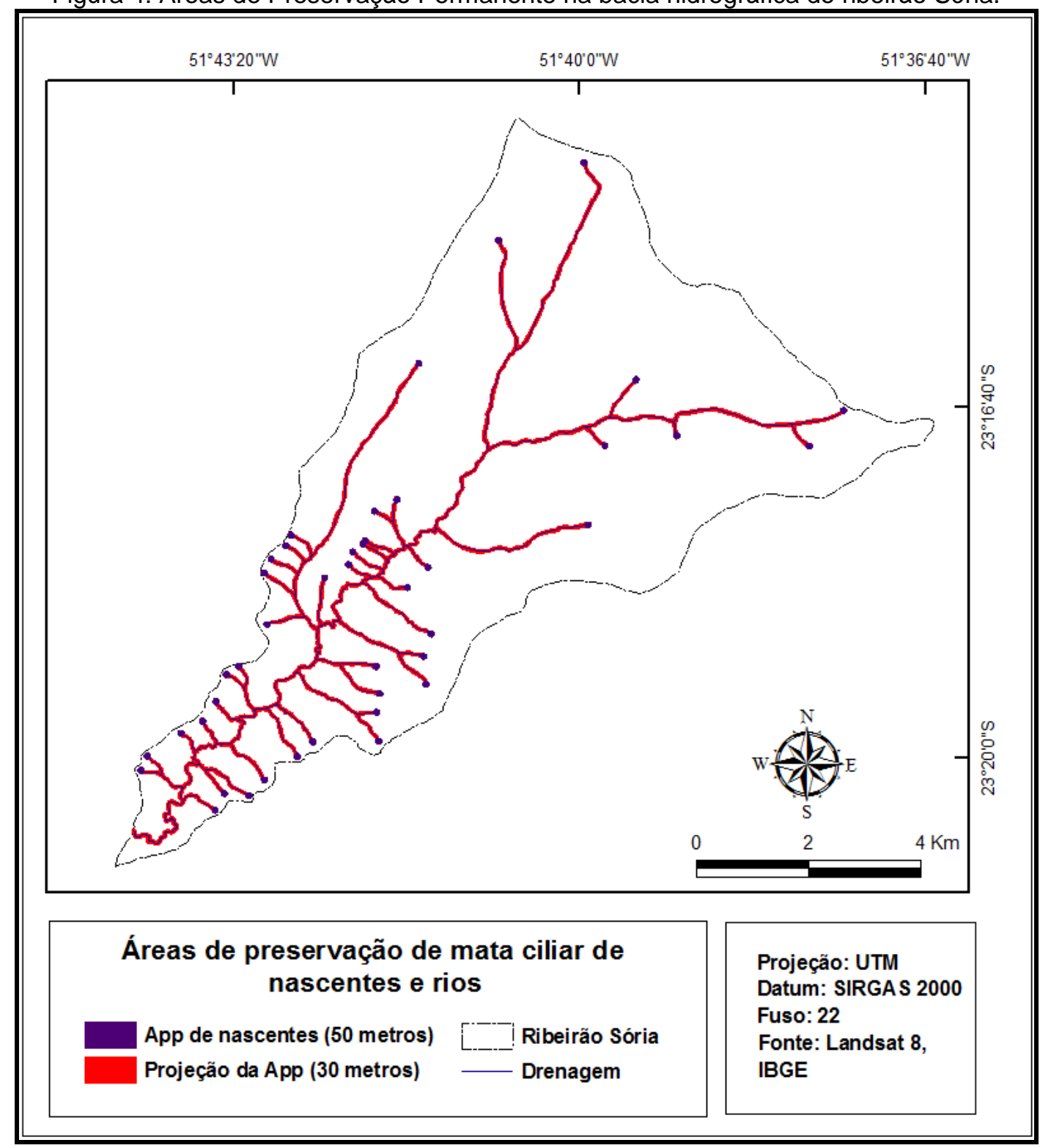

Todavia é possível perceber, ao observar o uso do solo com os limites de APPs (Figura 5), que grande parte da área da bacia não cumpre com o estabelecido 
pela Legislação. A maior parte das nascentes sequer apresenta faixa mínima de APP, assim como também não é em toda a extensão dos cursos d'água que há o acompanhamento das áreas de preservação permanente.

Figura 5: Uso do solo com projeção de APPs na bacia hidrográfica do ribeirão Sória.

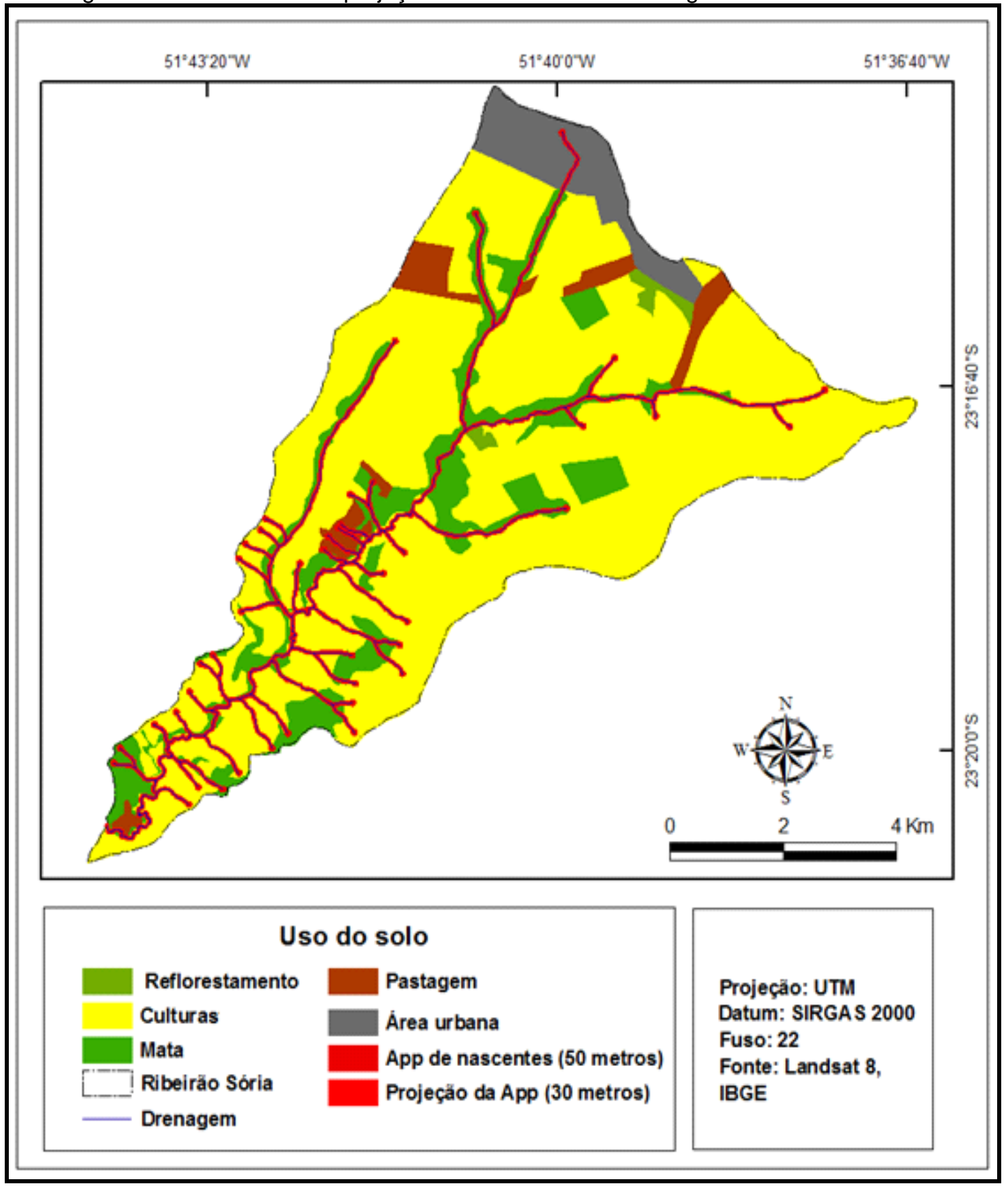

Já as Figuras 6 e 7, demonstram, por fim, a situação pretérita (2011) e atual (2015) da bacia hidrográfica do ribeirão Sória ao Código Florestal vigente, onde se 
levou em consideração a quantidade de área de preservação permanente, em km², para os anos em questão.

Figura 6: Área de Preservação Permanente na bacia hidrográfica do ribeirão Sória para o ano de

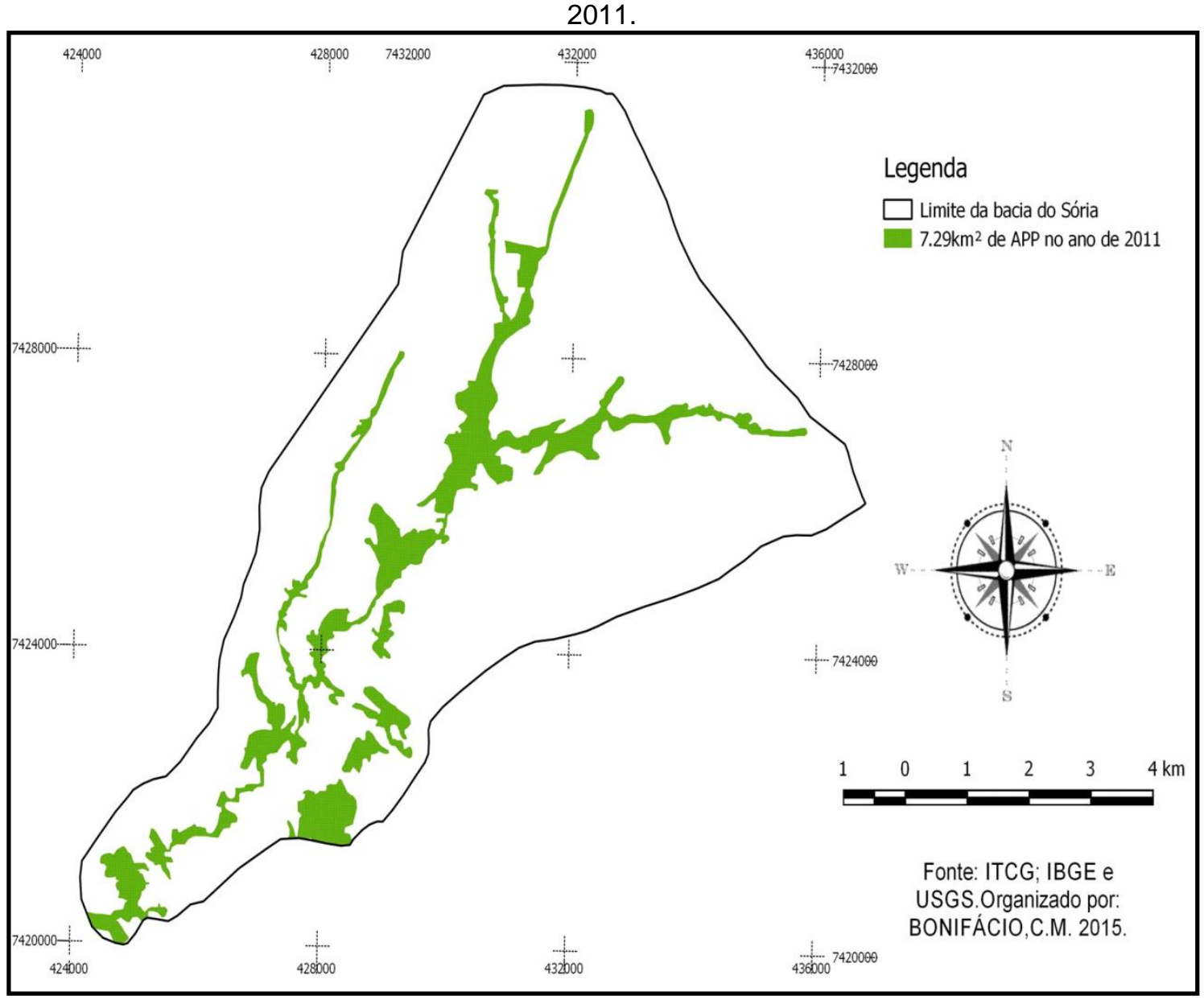


Figura 7: Área de Preservação Permanente na bacia hidrográfica do ribeirão Sória para o ano de 2015.

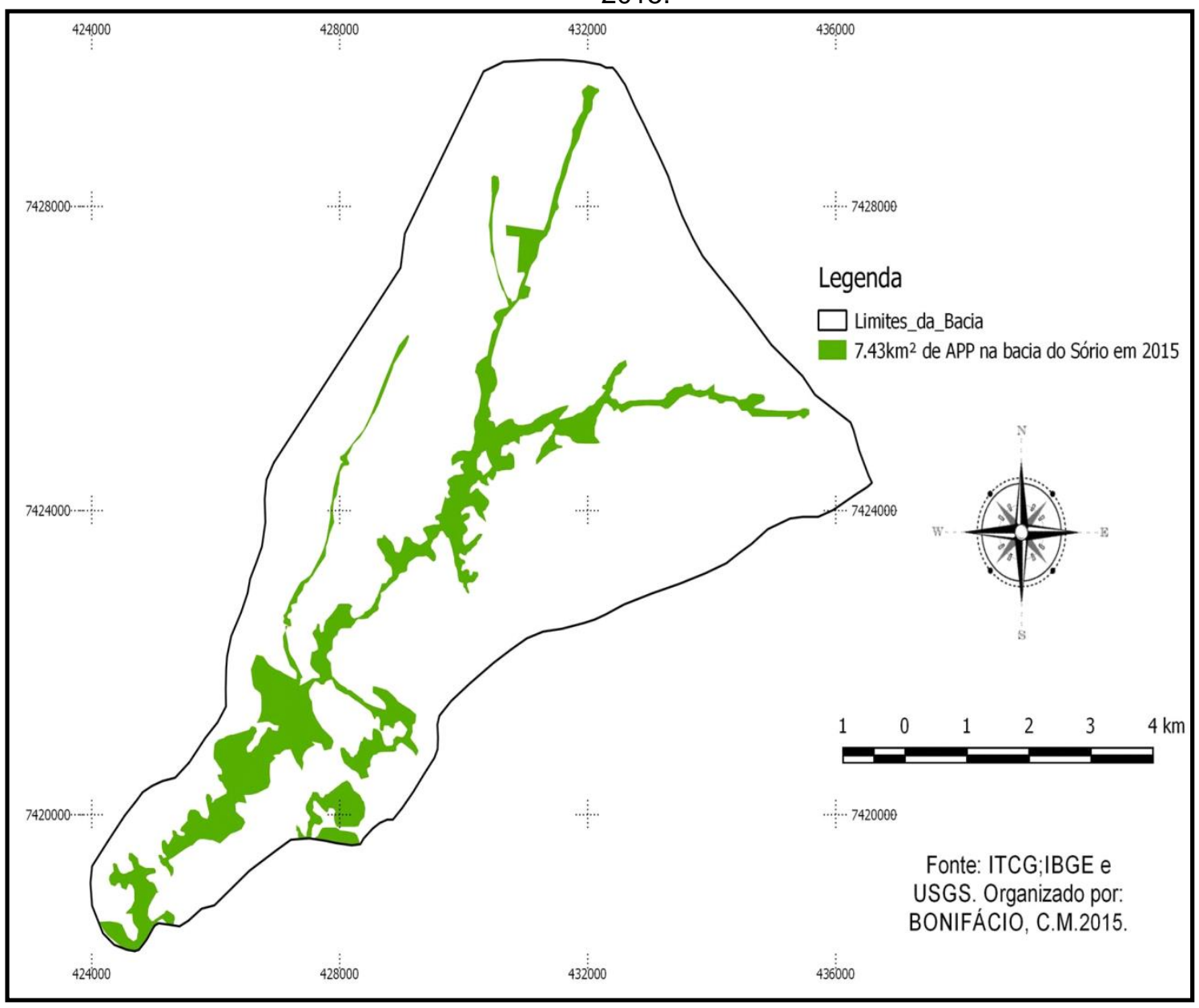

Na Tabela 2 é possível observar a quantidade de Área de Preservação Permanente na bacia hidrográfica do ribeirão Sória, no ano de 2011 e 2015.

Destaca-se o acréscimo de $0,14 \mathrm{~km}^{2}$ entre os anos selecionados, todavia, é importante mencionar que, ainda, apesar desse aumento de APP, muitas áreas de cursos d'água encontram-se em desacordo com a Legislação.

Tabela 2: Quantidade de área de APP em $\mathrm{km}^{2}$ na bacia hidrográfica ribeirão Sória.

\begin{tabular}{llc}
\hline APP & 2011 & 2015 \\
$\mathrm{~km}^{2}$ & 7,29 & 7,43 \\
\hline
\end{tabular}




\section{CONCLUSÕES}

A bacia hidrográfica do ribeirão Sória apresenta cursos d'água em divergentes faixas de Área de Preservação Permanente, sendo que, em alguns cursos o limite da APP encontra-se em desacordo com a Legislação.

Todavia, como foi possível observar que, apesar do decréscimo da faixa da APP, conforme o Código Florestal vigente, a área em questão apresentou um aumento de $0,14 \mathrm{~km}^{2}$ de vegetação.

Considera-se, dessa forma, a relevância deste tipo de estudo no que se refere à execução de planejamento ambiental, visando a sua preservação, pois através da utilização da carta topográfica e da aplicação de técnicas cartográficas é possível analisar e monitorar determinadas áreas, tornando-se assim uma ferramenta eficaz para o aferimento das leis ambientais.

\section{REFERÊNCIAS}

BONIFÁCIO, C. M. Avaliação da fragilidade ambiental em bacias hidrográficas do alto vale do rio Pirapó, Norte do Paraná: Proposta metodológica. Universidade Estadual de Maringá. Dissertação. Programa de Pós Graduação em Geografia. 110p. 2013.

BRAVO, J. V. M.; SANTIL, F. L. Avaliação da variação dos índices morfométricos de informações extraídas de cartas topográficas e implicações para a leitura do risco a enchentes. Revista Brasileira de Cartografia (2013) n.65/5, p.939-949.

CHRISTOFOLETTI, A. Geomorfologia. Ed.EDUSP. 1989. 149p.

FINOTTI, A. R.; CEMIN, G.; PÉRICO, E.Potencialidades do uso do sensoriamento remoto e dos sistemas de informação geográfica (SIGs) no ensino de hidrologia: a utilização de um estudo de caso. Rev. Geografia (Londrina), v. 20, n. 1, p.51-65. 2011

GUERRA, A. J. T. Encostas e a questão ambiental. In: A questão ambiental - Diferentes abordagens. Orgs. S. B. CUNHA, A. J. T. GUERRA. Ed. Bertrand Brasil. 1993. 248p.

MAACK, R. Geografia Física do Estado do Paraná. Curitiba: Badep: UFPR, 1968.

NOGUEIRA JÚNIOR, J. B. Controle de qualidade de produtos cartográficos: uma proposta metodológicas. Dissertação do programa de Pós graduação em Ciências Cartográficas, UNESP, 2003. 143p.

POLIZEL, S. P.; ROSSETTI, D. F. Análise morfométrica da bacia hidrográfica do córrego Tiradentes no município de Rio Bananal (ES). In: XCI Simpósio Brasileiro de Sensoriamento Remoto, 2013. 6p.

SANTOS, R. F. Planejamento ambiental: teoria e prática. São Paulo. Ed. Oficina de Textos, 2004. $184 \mathrm{p}$. 